\title{
Customer Brand Loyalty
}

\author{
Junjun Mao \\ Surrey International Institute, Dongbei University of Finance and Economics \\ 217 Jianshan Street, Shahekou District, Dalian 116025, China \\ Tel: 86-411-8471-0636 E-mail: mjjtracy@hotmail.com
}

\begin{abstract}
With the appearance of deceptive sales, poor customer care and crooked promotion, keeping loyal customers becomes even more difficult. Even though pursuing consumer reliability costs time and effort, it is really the most valuable asset of a successful company.
\end{abstract}

Keywords: Customer care, Brand, Customer loyalty, Brand loyalty

\section{Back ground information of customer brand loyalty}

Since the world is a global marketing now, competition among diverse corporations has become more drastic. In order to seize hold of the advantaged position in the marketplace, a mass of marketing specialists work out multifarious strategies to insure their triumph for a long time. Among these advanced strategies, developing and maintaining customer brand loyalty is considered to be a preferable option by more and more entrepreneurs. Nevertheless, there are still lots of people who refuse to attempt to this technique. They assert that it is impossible to achieve the ideal target, especially in the developed marketing economy. One can clearly see that even though pursuing consumer reliability costs time and effort, it is really the most valuable asset of a successful company.

\subsection{The definition of brand loyalty}

Brand loyalty is defined as keeping preferable to a specific product or service (BNET Business Dictionary). To rephrase it, faithful purchasers trend to pay money for the same brand of merchandise, and speak highly of its values. What' more, they believe that their choice is better than others.

\subsection{The development of the concept}

The notion of purchaser trustworthiness came through a long time and changed a lot. In an article by Gonring (2008, p.29), customer brand was given the definition of product quality before the 1980s. During the late 1980s and near the beginning 1990s, its emphasis changed from quality to customers. Still, with the competitors coming into the market in the late 1990s, satisfying and caring much about the clients became a much more significant object of many corporations. Since then, people have paid more and more attention on customer to make more profits.

\subsection{Four types of loyalty}

Customer brand loyalty has many aspects. Rowley (2005, p.574) concludes that there are four types of loyalty: captive, convenience-seekers, contented and committed. Captive customers prefer repeatedly purchasing the same product, service and brand because of lack of opportunities to substitute for alternatives. Convenience-seekers may not respect the brand itself, but look on the convenience that can carry. Contented consumers, however, have a positive attitude to a brand, but they won't attempt to some extra consumption. The perfect one is the committed, who are active both in attitude and behavior.

\section{Consumer brand loyalty has a significant position in the marketing.}

\subsection{Regarded as an essential feature of brand value}

It is admittedly true that shopper allegiance for a brand in truth contributes much to marketing. According to the concept of brand loyalty, it is regarded as the essential feature of brand value. The American Marketing Association gives it the explanation as "the situation in which a consumer generally pays money for the same manufacturer-originated product or service repeatedly over time rather than buying from multiple suppliers within the category" or "the degree to which a consumer consistently purchases the same brand within a product class"(2006, qtd in Moisescu).

The author draws attention to the fact that since other descriptive aspects of brand equity, such as considerable quality, associations and awareness, all have consanguineous relationship with purchase and appreciation, they 
can guarantee the level of brand loyalty. It follows that brand fidelity may add the satisfaction of other dimensions of brand value. For example, brand devotion always leads the payers to believe the perceived quality of the brand is better than others.

\subsection{Cut down costs}

This strategy may facilitate vendors expend less but attain utmost money in the marketing. The work of Reichheld (2000, qtd in Banasiewicz) reveals that sellers have to waste as much as four times money to attract new clients than to continue the loyal customer. On account of this, the author turned to a perfect statistic to prove this contention. He goes on to indicate that for an individual customer, you have to just spend 5 percent of wealth for keeping his loyalty; alternatively, you will receive $75 \%$ of profits that he will bring in. It can be comprehended as acquiring new purchasers expend more money to advertising, giveaway and industry discount.

\subsection{Less sensitive to price}

Typical loyal purchasers are less sensitive to price. Because of this, when a product mark up, they won't lessen the quantity of they buy. It is the view of Reilly (2008) that loyal customers deem the assessment of the product. As a consequence, they strong believe their choices. In that case, they trend to center less on the price.

\subsection{Bring in new potential faithful consumers}

The potential benefit that the loyal customers are able to add is that they may bring in more new consumers. At the same time, these potential consumers are also possible to become the future loyal customers. A good example of this is that when one repeatedly buy the same brand cosmetic, and consider it convenient to use, he will recommend it to his classmates and girl friend. Hence, there is no wonder that people around always own the same brand of clothes as well as other commodity. In contrast, if people around me complain the poor quality of a brand to me frequently, I won't think of owning it as well.

\subsection{Benefit in global marketplace}

Most of all, in the global economy, client brand dependability stands out as an important competitive weapon. Kust $(2008$, p.24) correctly argues that the world has switched into a global business in the last 10 decades; developing the brand loyalty globally is essential to enter the market. He goes on to indicate that in order to keep a trust relationship with their consumer, corporations should create a customer brand loyalty program among customers.

\section{Difficulties sometimes stop businessmen from working out the technology.}

\subsection{Purchasers refuse loyalty programs}

It is a popular belief, however, that we may find certain difficulties to face with consumer loyalty. First of all, Consumers are less willing to participate to customer loyalty program for several reasons. The excellent consumer loyalty program concludes both rewards and recognition; nevertheless, notwithstanding, the target doesn't make sense in the modern society. Thomas (2009, qtd in Silverstein) draws attention to the fact that with customers facing an array of choices, they will be particular about what they buy; as a consequence, we are paying more attention on the rewards of a product. It means that little rewards won't satisfy us any more. In other words, it is the modern economy environment that makes it more difficult for the sellers to remunerate people.

\subsection{Loyal programs is incomplete}

Yet another primary reason for non-participation is that customers have more requirements on loyalty program. According to Silverstein (2009), more than $50 \%$ of audiences complain that most loyalty programs look the same, so they lose interest to belong to any program. Worse still, some people who once took part in any loyalty program even drop out because of these two reasons.

At the same time, some people content that companies entrepreneurs shouldn't rely absolutely on customer fidelity. A good example of this is that current loyalty program exists some drawbacks which make its function incomplete (2003, Uncles, p.294). The author examines that most people trend to pay money for the product they require. In simpler terms, customers choose only one category of brands is an ideal condition.

\section{There are several infections of purchasers' loyalty.}

While it is true that retaining loyalty meets a lot of trouble, there is something can be done to reduce the risks. It can be clearly be maintained that finding the complication of brand loyalty can aid us solve the problems. To begin with, they should have a deep analysis of the customers' purchase inclination. For instance, what they would like to pay, how much they prefer to spent on the particular kind of good, and how often they go on shopping (Neuberger, 2008). 


\subsection{Brand reputation}

Enterprisers should pay more attention on the relationship of brand loyalty and brand reputation. Reference to Selnes (1996, p.19) reveals that, brand reputation is one of the most significant driver of brand loyalty, so it is efficient to pursue reputation for better consumer reliability. To put it briefly, having a good reputation means that customers are preferable for this product on attitude; hence, they will take action to buy this products. That is to say, brand reputation contributes to brand loyalty by increasing willingness and belief so that the attitude may change to behavior.

\subsection{Brand image}

Brand image play an important role in brand building, especially in customer dependability. As Reichheld (2001, qtd in Hsieh and Li, p.529) perceptively state that preferable brand image will lead consumers to conceive a perception of an organization's public relationship practice, which matches the corporate reputation better. With this in mind, customers are more likely to retain optimistic faith, attitude, and action. It must be therefore be acknowledged that customer loyalty grows fast through approving brand image.

\subsection{Consumers' satisfaction}

\subsubsection{Positive effect on a single product}

The evidence seems to be strong that when we talk about loyalty, we can't forget to mention customer satisfaction. Ha (2009, p.198) has expressed the view that satisfaction is a crucial factor of the customer performance and attitude. In the example, the researcher gets the data from different countries. Even though the culture is different, the result of the conclusion is the same.

\subsubsection{Weaker influence on brand alone}

It is a popular belief, however, that some people content that the condition of the effect of satisfaction depends. A good example of this is that when checking product singly, satisfaction is more indispensable. Conversely, its function becomes weaker in case of applying brand alone (2008, Torres-Moraga, p.302).

\subsection{Internal branding}

Internal branding is also a valuable outcome of brand loyalty. Internal branding affects mostly the employee's identification. What's more, empolyee's identification makes an positive effect on customer loyalty. It must therefore be recognized that internal branding contributes to customer loyalty (2009, Punjaisri, p.206).

\section{Corporations can do some effort to build and improve loyalty}

With this in mind, the wishes of businessman to achieve customer brand loyalty can indeed become a reality with several efforts. Supporters of the viewpoint assert that to remain a competitive business, companies should treat customers as friends (2007, Palmer). According to the author, in order to achieve this goal, managers should use the street teams, brand reps, and brand Ambassadors. And yet, street teams will work well, only by the audience fit the target.

\subsection{Pay more attention on customer care}

Customer care is considered a good point to building customer loyalty. As Webb (1999, p.72) has indicated that companies should think much about what the customers care. They can know much about the customers by asking a series of open-mind question. To be sure, the customer would like to talk deeply about their situation.

\subsection{Keep honest to customers}

Not only that, but also keeping honest to customers may retain customers' trust. As an illustration, online travel agency Orbitz Worldwide displays the actual price on the internet on the purpose of winning customers trust. On the contrary, numerous companies only show the basic rate on the internet. Actually, the price is a $15 \%$ higher (2009, Peterson). If we customers are treated fairly on the price, we would like to give out our trust.

\subsection{Measurement of loyalty}

Most of all, the measurement of the customer loyalty is another point that we need focus on. Turning to Terry, one finds that the good method to do measure is to separate 3 groups of the consumers according to the sore they receive. If they get the score 1-6, they are called detractors. The passives are those who have the score 7-8, and the promoters 'achieve are 9-10. Next, divide the total people who take part in the test with the promoters, and then you will get a percentage, which represents the level of your customer loyalty. He goes on to indicate that most companies get $10 \%-20 \%$ loyal clients. 


\section{Conclusion}

Customer brand loyalty came into enterprisers' eyes for several years. It plays a more and more important role in the modern global marketing. In order to maximize profit, people try different strategies, among which, loyalty is recognized by a large amount of businessmen. On the other hand, some may assert that it is a challenge to achieve it. Most of all, by finding the elements and effect of loyalty, businessmen may better understand the nature of consumer faith. For this reason, they may overcome the trouble in building and remaining customer reliability. In the final analysis, the technique will function better, because more and more people will contribute themselves to study the good method in the future.

\section{References}

Banasiewicz, Andrew. (2000). Keeping Your Best Customers Through Brand Loyalty.

Gonring, Matthew P. (2008). Customer loyalty and employee engagement: an alignment for value. Journal of Business Strategy. [Database] DUFE Library, Dalian. Assessed 18 Apr. 2009. [Online] Available: http://www.emeraldinsight.com/Insight/ViewContentServlet?Filename=Published/EmeraldFullTextArticle/Articl es/2880290404.html

Ha, Janda, and others. (2009). Role of satisfaction in an integrative model of brand loyalty." International Marketing Review. [Database].DUFE Library, Dalian. Assessed 18 Apr. 2009. [Online] Available: $\mathrm{http} / /$ www.emeraldinsight.com/Insight/ViewContentServlet?contentType=Article\&Filename=Published/Emeral dFullTextArticle/Articles/0360260204.html

Hsieh, An-Tien and Chung-Kai Li. (2008). The moderating effect of brand image on public relations perception and customer loyalty.[Database]. Marketing Intelligence \& Planning. DUFE Library, Dalian. Assessed 18 Apr. 2009.

[Online]

Available:

http://www.emeraldinsight.com/Insight/ViewContentServlet?contentType=Article\&Filename=Published/Emeral dFullTextArticle/Articles/0200260103.html

Kust, Mike. (2008). Brand Loyalty Goes Global Sales and Marketing Management. Vol. 160 Issue 1, p24-25.

Moisescu, Ovidiu Ioan. (2006). A Conceptual Analysis of Brand Loyalty as Core Dimension of Brand Equity. Craiova. [Online] Available: http://papers.ssrn.com/sol3/papers.cfm?abstract_id=1097716 (18 Apr. 2009)

Neuberger, Mickey. (2008). How to Reward and Keep Your Best Customers. [Online] Available: http://www.kiplinger.com/businessresource/recommend/archive/2008/customers-loyaltylab.html (19 Apr. 2009)

Palmer, Justin. (2005). Building loyalty: building customer for life. Assessed 25 May. 2009, [Online] Available: http://www.palmerwebmarketing.com/blog/brand-loyalty-building-customers-for-life/

Peterson, Kyle. (2009). Orbitz aims for brand loyalty with new price display. .[Online]Assessed 25 Apr. 2009. [Online] Available: http://money.aol.ca/article/orbitz-aims-for-brand-loyalty-with-new-price-display/604727/

Punjaisri, Evanschitzky and others. (2009). Internal branding: an enabler of employees' brand-supporting behaviors. [Database]. Journal of Service Management. DUFE Library, Dalian .Assessed 11 Apr. 2009, [Online] Available:

http://www.emeraldinsight.com/Insight/ViewContentServlet?contentType=Article\&Filename=Published/Emeral dFullTextArticle/Articles/0850200205.html

Reilly, Tom. (2008). Dealing with price sensitivity. Industrial Distribution. [Online]Assessed 18 Apr. 2009. [Online] Available: http://www.inddist.com/article/170985-Dealing_with_price_sensitivity.php

Rowley, Jennifer. (2005). The four Cs of customer loyalty. [Database] Marketing Intelligence \& Planning. DUFE Library, Dalian. Assessed 12, Apr. 2009. [Online] Available: http://www.emeraldinsight.com/Insight/ViewContentServlet?contentType=Article\&Filename=Published/Emeral dFullTextArticle/Articles/0200230604.html

Selnes, Fred. (1993). An Examination of the Effect of Product Performance on Brand Reputation, Satisfaction and Loyalty. [Database] European Journal of Marketing. DUFE Library, Dalian. Assessed 18 Apr. 2009. [Online] Available:

http://www.emeraldinsight.com/Insight/ViewContentServlet?contentType=Article\&Filename=Published/Emeral dFullTextArticle/Articles/0070270902.html

Silverstein, Barry. (2009). Can Brand Loyalty Be Bought?. [Online] Available: http://www.brandchannel.com/start1.asp?fa_id=475 (1 May. 2009)

Torres-Moraga, Vásquez-Parraga and others. (2008). Customer satisfaction and loyalty: start with the product, 
culminate with the brand. [Oneline] Journal of Consumer Marketing.DUFE Library, Dalian. [Online] Available: http://www.emeraldinsight.com/Insight/viewContentItem.do;jsessionid=1613145CB16

DD07F73CC38220C277991? contentType $=$ Article \& contentId $=1737912$ (18 Apr. 2009)

Terry, Gregg. (2009). The Ultimate Question - One Way To Measure Customer Loyalty. [Online] Available: http://ezinearticles.com/?The-Ultimate-Question---One-Way-To-Measure-Customer-Loyalty\&id=306493 Apr. 2009)

Uncles, Dowling, and others. (2003). Customer loyalty and customer loyalty programs. Journal of Consumer Marketing. 2003. pp. 294-316.

Webb, Laverne Dees, and Steve Cooperman. (1999). Improve your organization's results. [Online] Available: http://www.encompassworld.com/publications/article_results.pdf (22 Apr. 2009.).

"Business Definition for: Brand Loyalty". [Online] Available: http://dictionary.bnet.com/definition/Brand+Loyalty.html?tag=col1;rbDictionary (8 Apr. 2009.).

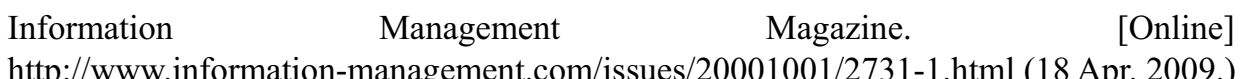

Available: 